\title{
OVERVIEW OF CURRENTLY USED WIRELESS ELECTRICAL VEHICLE CHARGING SOLUTIONS
}

\author{
Damian Dobrzański \\ Lublin University of Technology, Faculty of Electrical Engineering and Computer Science, Department of Electrical Machines and Drives
}

Abstract. This article describes the current systems for wireless electrical vehicles charging available for use and ideas how to improve efficiency of them, differences between active and passive (static) contactless charging and also institutions and companies which work on development this kind of technology.

Keywords: wireless charging, electrical vehicles, contactless charging, active charging, EVSE

\section{PRZEGLĄD WYKORZYSTYWANYCH BEZPRZEWODOWYCH SYSTEMÓW LADOWANIA POJAZDÓW ELEKTRYCZNYCH}

Streszczenie. Artykut opisuje aktualnie dostępne systemy bezprzewodowego ładowania pojazdów elektrycznych oraz koncepcje zwiększenia ich sprawności, różnice pomiędzy aktywnym oraz pasywnym (statycznym) tadowaniem bezstykowym a także instytucje i firmy pracujące nad rozwojem tych technologii.

Słowa kluczowe: ładowanie bezprzewodowe, pojazdy elektryczne, ładowanie bezstykowe, aktywne ładowanie, pojazdy elektryczne

\section{Introduction}

In the last few years, the automotive world is turn back to history. It`s really hard to say when and who was built the first electric vehicle but with a lot of probability it was created between $1832-1839$ by Robert Anderson [20]. But in 1900 in USA car production was equal 1575 electric vs. 936 petrol car. The most of society doesn't even know about it and take electric cars for a new gadget, but if we look for dates someone could say "Electric cars is nothing new" and he has the right. As we can see when we are looking at a market, electric vehicles are becoming more popular. All major car producers have or plan to have in their offer electrical models. This kind of revolution brings many advantages like cleaner air with less pollution, higher efficiency of car engine (petrol engine achieves efficiency near to $40 \%$ as opposed to electrical engines with efficiency higher than 90\%) and finally while using EV (electrical vehicle) we can significantly reduce greenhouse gases. The most important limitation of $\mathrm{EV}$ is range which is directly connected to energy density, for example in gasoline this value is $46 \mathrm{MJ} / \mathrm{kg}$ and in lithium-ion battery is less than $1 \mathrm{MJ} / \mathrm{kg}$ [11]. It only means that we have to fill the battery more often than the petrol car. The most used kind of charging EV is standard electrical plug with cable connected to home socket or using EV fast chargers mounted in parking lots near large-area shop or tank station or less in public places. For now we have four most popular standards of chargers, with different plug and charging power. Driver needs to know where is the charger which is compatible with his car, then park car in range of cable, go out from vehicle, authorize himself in system and connect it to charger to start charging. This solution takes priceless time and is uncomfortable when outside car is bad weather.

This paper is a short overview of few chosen solution which could remedy this, all of them can be described as a wireless vehicle charging system. The aim of the article is to present existing contactless solutions for both individual users as well as for companies and public space.

\section{Standards of conventional charging of electric vehicles}

The beginnings of the actually existing standard dates back to 2003 when is published by International Electrotechnical Commission (IEC) in IEC 62196 documents. Today all types of wired EV charging should be compatible with requirements described in IEC 62196 standard documentation which is divided to three parts. First - IEC 62196-1 which describes general information about interface between charging station and electric vehicles. Second - IEC 62196-2 describes dimensional compatibility and interchangeability requirements for alternating current (AC) charging and the third - IEC 62196-3 where have been included requirements for direct current (DC) or AC/DC charging [17]. Right now we have four most popular standards based on IEC 62196 which is use to charge electrical vehicles. The first one is 62196 - type 1 - American and 62196 - type 2 European version of AC charging, second is Combo Charging System (CCS) which is also divided to American and European versions, this standard was first time connected AC and DC fast charging in one plug. The most important different between US and EU types are number of using AC phases this is due to the greater popularity of the three-phase network in Europe. Third is Japanese CHAdeMO-DC fast charging standard and the last one is Tesla Supercharger. The most important technical parameters and differences between them was shown in Table 1 .

Table 1. The most important parameters of wired charging standards for electrical vehicles $[17,19,21]$

\begin{tabular}{|c|c|c|c|c|}
\hline Name & $\begin{array}{c}\text { Voltage } \\
{[\mathrm{V}]}\end{array}$ & $\begin{array}{c}\text { Current } \\
{[\mathrm{A}]}\end{array}$ & $\begin{array}{c}\text { Power } \\
{[\mathrm{kW}]}\end{array}$ & Communication \\
\hline $62196 \mathrm{US}$ & $240 \mathrm{AC}$ & 80 & 19.2 & PLC \\
\hline $62196 \mathrm{EU}$ & $480 \mathrm{AC}$ & 63 & 30.2 & PLC \\
\hline CCS1 & $500 \mathrm{DC}$ & $<400$ & 200 & PLC \\
\hline CCS2 & $500 \mathrm{DC}$ & $<400$ & 200 & PLC \\
\hline CHAdeMO & $500 \mathrm{DC}$ & $<125$ & 62.5 & CAN-bus \\
\hline Tesla super-charger & $480 \mathrm{DC}$ & $<250$ & 120 & PLC \\
\hline
\end{tabular}

\section{Wireless energy transfer the obsession of Nikola Tesla}

First time energy was transferred contactless probably by Nikola Tesla in 1891 to supply lighting bulb, this concept is shown in Figure 1. Two vacuum tubes lighted in an alternating electrostatic field while held in the hand of the experimenter hand. Between two metal plates each being connected to one terminal of the induction coil secondary winding, was created electric field [17]. We can speculate that he did not suspect that his concept will be used after more than 100 years to charge many devices, from smartphones, smartwatches to electrical vehicles. First hands-free wireless charging had its debut in 2002 in Turin and Genoa to charge electrical buses. Contactless power transfer system was made by German company Conductix-Wampfler and it is still working to this day. Since 2009 wireless charging has been divided into two types, passive (stationary) and active (on line charging or charging on move). 


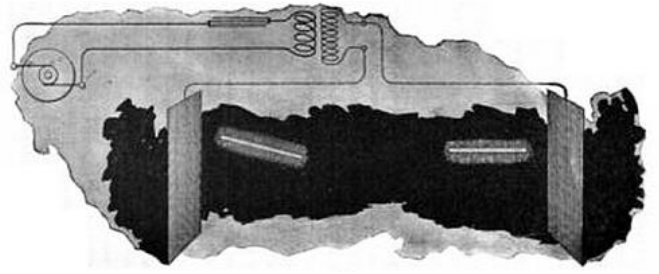

Fig. 1. Tesla`s wireless energy transfer concept [19]

To understand the idea how wireless charging works we need to know what conventional charger is built of. As is shown in Figure 2 we can see two pairs of transistors (S1,S2 and S4,S3 or $\mathrm{S} 5, \mathrm{~S} 6$ and $\mathrm{S} 7, \mathrm{~S} 8$ ) for each side of charger, connected to DC bus, in the centre there is a transformer with galvanic isolation. Number of turns on primary and secondary side is strictly related to power of the charger. After transistors there is a low pass filter and a load, depicted by battery symbol. Transistors turn on and off in pairs as below, to deliver power when it is necessary. Transformer is used to achieve the required level of safety The wireless charger isn`t more complicated than typical fast charger. To build this kind of power transmission station we need to replace transformer with galvanic isolation with two coils transmitter (Tx) and receiver (Rx) and design compensation system for each of parts as is shown on Figure 3, rest of the circuit could be similar.

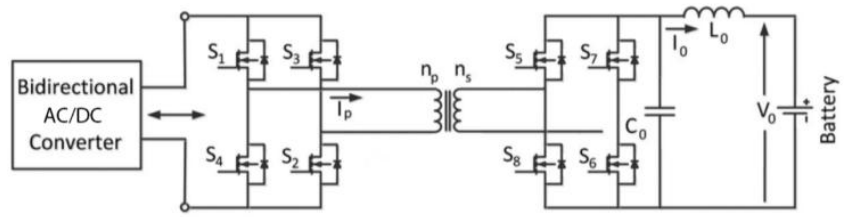

Fig. 2. Bidirectional EV fast charger topology [10]

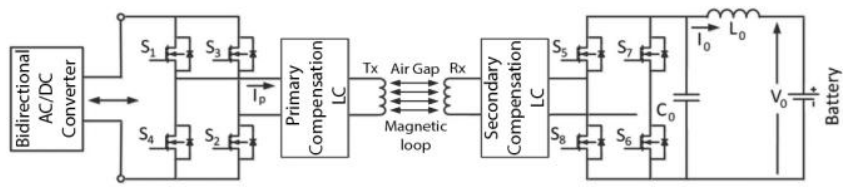

Fig. 3. Bidirectional EV wireless charger topology

In wireless power transfer (WPT) [14] the transmitter and receiver coils together form transformer with larger air gap than it is in conventional charger. The current flowing through to the Tx coil creates an oscillating magnetic field which is passes through the $\mathrm{Rx}$ coil. This phenomenon was found and described by Faraday, it's induces a AC voltage in Rx terminal. Inducted voltage can be used directly or rectified by receiver [6]. In this topology voltage on Rx clamp is rectified by four controllable transistors and deliver to load. Of course each coil should be calculated for assumed power, frequency and voltage. However, designer must be aware of the limitations resulting from this kind of solution. The most important of the aforementioned restrictions is distance between coils which in a three-dimensional coordinate system is defined as the "z-axis" variable, second one is centering of both coils it's the "x-axis" and " $y$-axis" variable correlation bad and good configuration was shown in Figure 4. WPT technology is a collective name for any solution which is use to wireless energy transfer, it`s divided to six types for different technology and possible current or possible future applications starting at portable devices charging and ending on biomedical implants or MAGLEV (Magnetic Levitation) trains [1]. The Division and exemplary use are presented in Table 2 and Table 3. Wireless Power Transfer includes technologies like inductive coupling, resonant inductive coupling, capacitive coupling, magnetodynamic coupling, microwaves, light waves.

It should be honestly acknowledged that if the distance between the coils is too large and their arrangement significantly deviates from the central one, charging process could be ineffective or not start at all.
Table 2. The most important parameters of WPT types part $1[1,8]$

\begin{tabular}{|c|c|c|c|}
\hline Technology & $\begin{array}{c}\text { Inductive } \\
\text { Coupling }\end{array}$ & $\begin{array}{c}\text { Resonant } \\
\text { Inductive } \\
\text { Coupling }\end{array}$ & $\begin{array}{c}\text { Capacitive } \\
\text { Coupling }\end{array}$ \\
\hline Range & Short & Medium & Short \\
\hline Directivity & Low & Low & Low \\
\hline Freq. & $\mathrm{Hz}-\mathrm{MHz}$ & $\mathrm{kHz}-\mathrm{GHz}$ & $\mathrm{kHz}-\mathrm{MHz}$ \\
\hline Antenna & Wire coils & $\begin{array}{c}\text { Tuned coils, lumped } \\
\text { resonators }\end{array}$ & $\begin{array}{c}\text { Metal plate } \\
\text { electrodes }\end{array}$ \\
\hline $\begin{array}{c}\text { Current and } \\
\text { possible } \\
\text { applications }\end{array}$ & $\begin{array}{c}\text { EV charging, tooth } \\
\text { brush, stovetops }\end{array}$ & $\begin{array}{c}\text { Portable devices, } \\
\text { Maglev, trains, RFID }\end{array}$ & $\begin{array}{c}\text { Large scale } \\
\text { routing, } \\
\text { smartcards, } \\
\text { implants }\end{array}$ \\
\hline
\end{tabular}

Table 3. The most important parameters of WPT types part $2[8,9]$

\begin{tabular}{|c|c|c|c|}
\hline Technology & $\begin{array}{c}\text { Magneto-dynamic } \\
\text { coupling }\end{array}$ & Microwaves & Light waves \\
\hline Range & Short & Long & Long \\
\hline Directivity & N.A. & High & High \\
\hline Freq. & $\mathrm{Hz}$ & $\mathrm{GHz}$ & $\geq \mathrm{THz}$ \\
\hline Antenna & Rotating magnets & $\begin{array}{c}\text { Parabolic dishes, } \\
\text { phased arrays }\end{array}$ & $\begin{array}{c}\text { Lasers, } \\
\text { photocells }\end{array}$ \\
\hline $\begin{array}{c}\text { Current and } \\
\text { possible } \\
\text { applications }\end{array}$ & $\begin{array}{c}\text { EV charging, buses, } \\
\text { implants }\end{array}$ & $\begin{array}{c}\text { Solar powered } \\
\text { satellite, powering } \\
\text { drone, charging } \\
\text { devices }\end{array}$ & $\begin{array}{c}\text { Charging } \\
\text { devices, } \\
\text { powering space } \\
\text { elevator } \\
\text { climbers }\end{array}$ \\
\hline
\end{tabular}
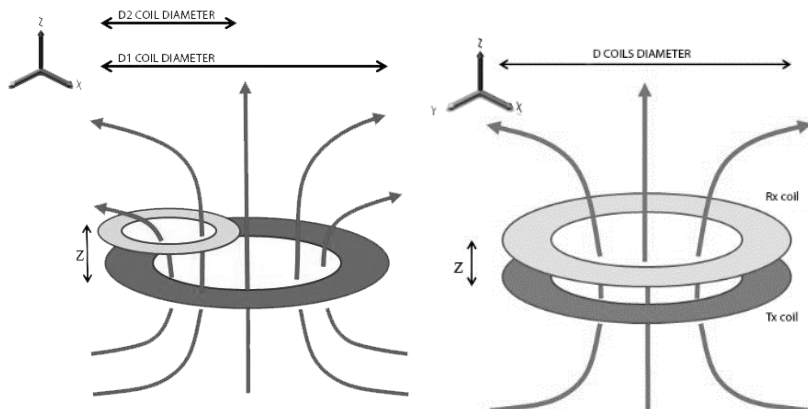

Fig. 4. Bad-not centralized coils in Cartesian coordinates, and on the right side correctly designed coil system

\section{Overview of existing commercial wireless charging station for electrical vehicle}

In this chapter there are shown chosen wireless charging stations which are currently under development or have been recently introduced to the market.

\subsection{Qualcomm Halo}

First one of wireless charging solutions which is described in this paper is project Halo WEVC (Wireless Electric Vehicle Charging) from Qualcomm. This American company is one of the largest CPU producers (Central Processing Unit) for handheld electronics like navigation units, smartphones, tablets and many other devices.

Qualcomm Halo assumes wide availability of parking places equipped with wireless charging station, if they plan was done, users will be able to charge their cars almost anywhere, near work, shop, church, school etc. A long awaited premiere of wireless charging car solution from BMW based on Qualcomm technology took place on 28th May 2018. It's first vehicle with factory fitted (optional of course) inductive charging. Whole system consists of "GroundPad" - this element is nothing else than Tx coil with security electronics in sealed case which could be used indoor and also outdoor, Rx coil fitted to car chassis to receive energy and set of sensors to navigate driver to park directly above GroundPad [16] as is shown in Figure 6. Producer claims system charging power at $3.2 \mathrm{~kW}$ level with efficiency rate near $85 \%$. For now 
GroundPad can be only leased. The other cars with Qualcomm Halo charging solutions include Rolls Royce 102EX and Renault ZOE, but Qualcomm is an active member of standards development organizations as ISO, IEC and SAE. It should be added that the Qualcomm Halo technology allows to charge up to $22 \mathrm{~kW}$ from 3-phase grid. Qualcomm Halo is aimed to OEM producers and right now it is futile to look for it on free market.

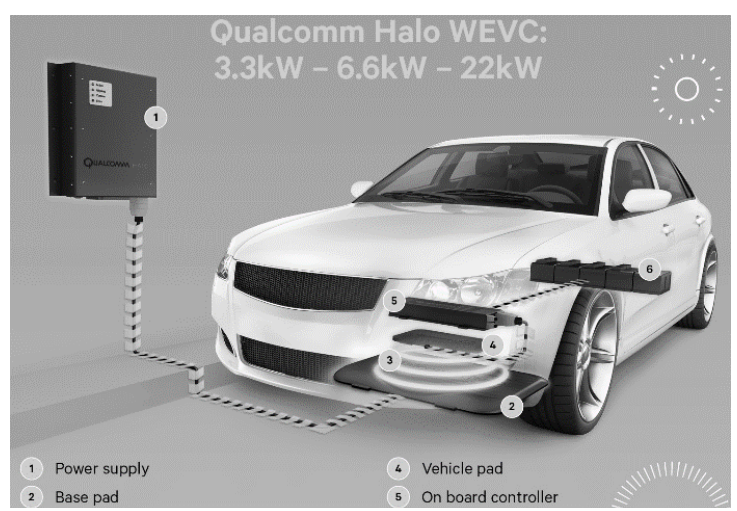

Fig. 6. Qualcomm Halo WEVC system diagram [16]

\subsection{Plugless Power}

Another solution is "Plugless Power". It's a proposal from Plugless company which is founded by Evatran in 2009 year, after TED conference (Technology, Entertainment and Design). Similarly to Qualcomm, we have system built from two coils, one $\mathrm{Tx}$ in charging pad, second $\mathrm{Rx}$ in car chassis and wall control panel as is shown on draft in Figure 7.

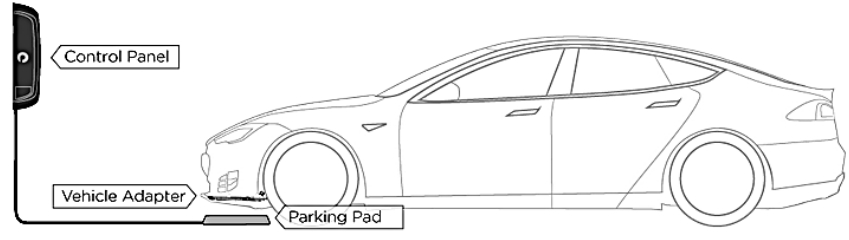

Fig. 7. Draft of the Plugless Power charging system [15]

Plugless Power charging system is tested and compatible with Tesla S, BMW i3, Chevrolet Volt, Nissan Leaf. For this car, Plugless offers on free market ready plug\&play systems with two charging power configurations which are described in Table 3 [15]. This kind of company policy supports popularization of electrical vehicles and their wireless charging among noncommercial customers. Unfortunately right now company doesn`t have European version of charging devices.

Table 3. Plugless Power technical parameters

\begin{tabular}{|c|c|c|}
\hline Parameter & \multicolumn{2}{|c|}{ Charging power } \\
\hline Charging power & $3.2 \mathrm{~kW}$ continuous & $7.2 \mathrm{~kW}$ continuous \\
\hline Input voltage & $120 \mathrm{~V}$ (US type) & $240 \mathrm{~V}$ (US type 2 phase) \\
\hline Connection & NEMA 5-15 & Nema 14 - 50 \\
\hline $\begin{array}{c}\text { Required connection } \\
\text { current }\end{array}$ & $30 \mathrm{~A}$ wall socket & $50 \mathrm{~A}$ wall socket \\
\hline $\begin{array}{c}\text { Durability of charging } \\
\text { pad }\end{array}$ & $680 \mathrm{~kg}$ (per wheel) & $680 \mathrm{~kg}$ (per wheel) \\
\hline $\begin{array}{c}\text { Temperature range } \\
\text { Distance between } \\
\text { charging coils (Air Gap) }\end{array}$ & $-30^{\circ} \mathrm{C}$ to $50^{\circ} \mathrm{C}$ & $-30^{\circ} \mathrm{C}$ to $50^{\circ} \mathrm{C}$ \\
\hline Ground clearance & $10 \mathrm{~cm}$ & $10 \mathrm{~cm}$ \\
\hline
\end{tabular}

\subsection{OLEV}

In conventional contactless chargers solution users must find parking place with wireless charger, park and wait to charge their vehicles. Unfortunately even contactless charging or typical cable charging does not solve problems with range in one battery charge, but OLEV technology approached this issue completely differently.

OLEV (On-Line Electric Vehicle) technology was created in Korea Advanced Institute of Science and Technology (KAIST) where was first time tested [13]. This kind of charging system uses SMFIR (Shaped Magnetic Field in Resonance) technology [16] Now OLEV is developed by two companies, OLEV Korea and OLEV Boston. OLEV technology is focused on buses and trucks, because it s weight is around $200 \mathrm{~kg}$ per vehicle and is too heavy for passenger cars. This make sense with big transit buses and trucks where length of vehicle combination is greater than for example Nissan Leaf, and $200 \mathrm{~kg}$ more doesn't make a huge difference especially when it could reduce weight of battery without any negative impact to range, that allows to transport heavier loads. Another idea of using OLEV is equipping airports with this technology, every vehicle in closed area of airports could be charging directly from lane, without any air pollutions.

Active charging conception, as is shown in Figure 8 is based on cables or coils under the street surface and appropriate modulation parameters of the voltage flowing through them and adapted, compatible electrical vehicles.

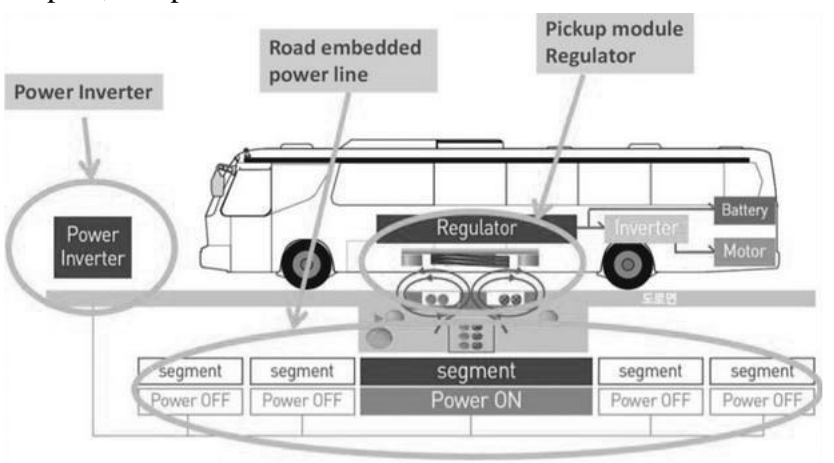

Fig. 8. OLEV active charging system [3]

This mass-scale solution is still the future, but when road and infrastructure managers equips roads with this system, a real revolution may take place. Users will stop worrying about range of their electrical vehicles, because they will be online charging when they drive on specially designated road lanes. This technology could significantly increase EV`s sales.

\subsection{Bombardier primove}

Another big company that has made a large investments is Bombardier, company known for the production of aircraft. Their product is named primove and it's really complex, starting from electrical cars, via e-buses, e-trucks and finally to trams. For electrical cars solution is similar to Plugless Power, but for ebuses, e-trucks and trams it introduces an innovative approach.

E-buses, huge percentage of this car type are using in cities to transport citizens between bus stops. In other solutions e-buses were charging only on bus depot or wirelessly from road lane. First type is uncomfortable and the second one is too expensive right now because it requires completely road renovation and road infrastructure. Bombardier solution is cheaper and more realistic, they propose to revitalize bus stops and put charging transmitting coils under stops area. Someone after reading that could say, "ok, but is nothing new" but primove is a smart charger, when e-bus approaches the stop, charging pad under surface is launched and $\mathrm{Rx}$ coil on e-bus chassis is lowered directly above Tx coils as was shown on Figure 9. The only obstacle between coils is material of bus stop surface. That solutions can improve speed, power and efficiency of wireless charging, and also is invisible to citizens so what is really important in old town area it doesn `t disturb in urban architecture [12].

Trucks, vehicles are responsible for transporting large objects and loads but also for generating large quantity of greenhouse gases. In last quarter of 2017 Tesla shown their first electrical 
truck prototype which name is Tesla Semi, truck with huge range, near $800 \mathrm{~km}$ - but it's a prototype. Bombardier found solution also for trucks, they propose to build trucks wireless fast charging ports not only in gas stations but primarily on most of delivery points. That provides to driver but more to their company and delivery point environment becomes more comfortable, clear and cheap solution than petrol trucks, without any greenhouse gases.

Solution for trams, similarly to e-buses is designed directly for cities, in conventional systems trams riding on rails and are powered from overhead lines, this type of power also interferes with architecture.

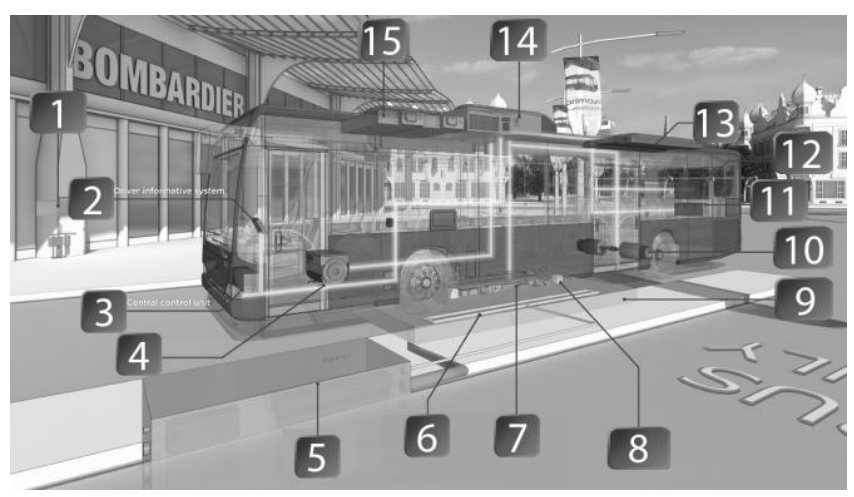

Fig. 9. Bombardier primove, contactless charging system for e-buses [12]:

1 - cooling unit, 2 -driver information system, 3 -central control unit, 4 - steering pump, 5 - wayside electrical installation, 6 - vehicle detection, 7 - pick - up system, 8 - onboard sending device, 9 - charging slab, 10 - traction motor, 11 - 24V battery, 12 - heating, 13 - HVAC, 14 - primove propulsion system, 15 - primove battery system

Primove proposes to connect static contactless charging with active charging similar to OLEV, but static charging should be in designated trams stops and the active charging should be calculated and placed in the critical parts of lines. This solution is less expensive than full OLEV technology and more comfortable than only trams stops, this concept is shown in Figure 10. Another advantages are minimising of architecture pollution, easy way to install equipment in new or existing lines of trams because all elements fit in space between tram rails, also entire system is compatible with e-bus, that means in one investment cities could use infrastructure for trams and e-buses, that is a big benefit also for citizens, because city government will save huge money.

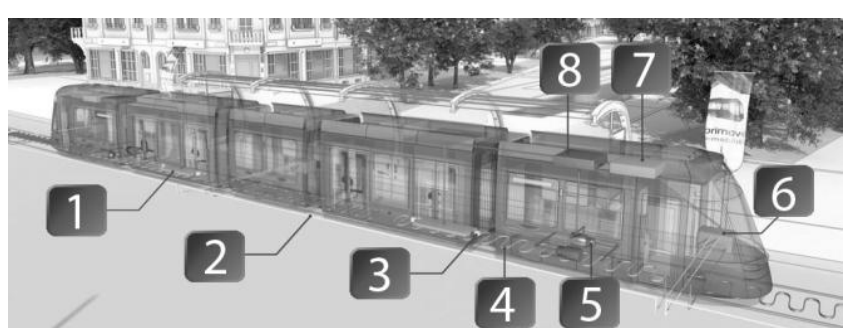

Fig. 10. Bombardier primove, contactless charging system for trams [12]: 1-pickup system, 2 - vehicle detection, 3 - onboard sending device, 4 - charging segment, 5 -traction motor, 6 -inverter, 7- primove battery system, 8 - power management

\section{Conclusions}

The biggest problem with contactless energy transfer (CET) [5] charging is lower efficiency compared to conventional solutions and loses resulting from air gap and dirt accumulating on the coils. However it is possible to reduce losses in components of charger by changing technology of used elements. For example: changing using propylene capacitors can reduce dielectric losses by $2 \%$, or changing IGBT transistors to SiC MOSFET can reduce inverter losses by 4\% [2]. Unfortunately it doesn't solve the problem with losses resulting from air gap, to reduce this value proposal from primove seems to be justified, when we stop on charging point $\mathrm{Rx}$ coil or coils are lowered to the ground and lay directly above Tx coils, the only obstacle between them is surface area of the substrate which scientists and engineers should choose or develop in way to minimizes contactless transfer losses. Another concept to reduce losses in inductive power transfer (IPT) circuit is compensation inductance leakage by appropriate connected capacitor to reduce losses on AC side [4]. At this paper was shown few comfortable ways to charge electrical vehicles, this solution can contribute to popularization of EV`s and reduction of greenhouse gases. Also all electrical vehicles can be considered a form of distributed energy storage which can be charge when grid is oversupplied or can transfer energy to the grid when it is necessary [7].

\section{References}

[1] Chung Y. D., Kim J. Seong.: Improved Efficiency Characteristics of Wireless Power Charging System for Superconducting MAGLEV Train Using Inserted Permanent Magnets. 2018 IEEE International Symposium on Electromagnetic Compatibility and 2018 IEEE Asia-Pacific Symposium on Electromagnetic Compatibility (EMC/APEMC), 2018. 564-567.

[2] Fatyga K., Kwaśny Ł., Stefańczak B.: A comparison study of the features of DC/DC systems with $\mathrm{Si}$ IGBT and $\mathrm{SiC}$ MOSFET transistors. Informatyka, Automatyka, Pomiary w Gospodarce i Ochronie Środowiska - IAPGOS 2/2018, $68-71$

[3] Jeong S., Jang. J. Y, Kum D.: Design optimization of the OLEV system considering battery lifetime. 17th International IEEE Conference on Intelligent Transportation Systems ITSC, 2014, 2492-2498.

[4] Kaźmierkowski M. P., Miskiewicz R. M., Moradewicz A. J.: Inductive Coupled Contactless Energy Transfer Systems - A Review. Selected Problems of Electrical Engineering and Electronics WZEE, IEEE Conferences 2015, 1-6.

[5] Kaźmierkowski M. P., Moradewicz A. J.: Unplugged But Connected - Review of Contactless Energy Transfer Systems. IEEE Industrial Electronics Magazine $4 / 2012$, vol. $6,47-55$.

[6] Lu X., Wang P., Niyato D., In Kim D., Han Z.: Wireless Charging Technologies: Fundamentals, Standards, and Network Applications. IEEE Communications Surveys\&Tutorials, vol. 18, 2016, 1413-1452.

[7] Ludwinek K., Staszak J., Nadolski R., Gawecki Z., Kurkiewicz J., Bekier T.: Simulations and Experimental Investigations of an Impulse System for Battery Charging in Electric Bike. Analysis and Simulation of Electrical and Computer Systems, Springer International Publishing AG 2018, 219-228.

[8] Shinohara N.: Wireless Power Transfer via Radiowaves. John Wiley\&Sons, 2014.

[9] Sun T., Xie X., Wang Z.: Wireless Power Transfer for Medical Microsystems. Springer Science \& Business Media, 2013.

[10] Tokovarov M., Zieliński D.: Simulation and comparison of selected fast charger topologies. Informatyka, Automatyka, Pomiary w Gospodarce i Ochronie Środowiska - IAPGOS 3/2017, 23-28.

[11] http://batteryuniversity.com/ BatteryUniversity (available: May 2018)

[12] https://primove.bombardier.com Bombardier primove (available: July 2018).

[13] http://www.chargedevs.com Charged, Electric vehicles magazine, (available: July 2018)

[14] IEC 61980-1 Ed. 1.0, Electric vehicle wireless power transfer (WPT) systems Part 1: General Requirements, 2015, received June 2018

[15] https://www.pluglesspower.com Plugless Power (available: June 2018).

[16] https://qualcomm.com Qualcom Halo (available: June 2018)

[17] Standard IEC 62196 - Plugs, socket-outlets, vehicle connectors and vehicle inlets - Conductive charging of electric vehicles - Part 1, 2, 3, (available: August 2018).

[18] https://www.tesla.com/supercharger Tesla Motors (available: July 2018).

[19] https://teslaresearch.jimdo.com/wireless-transmission-of-energy-1/ Teslaresearch, (available: June 2018)

[20] https://www.thoughtco.com ThoughtCo. "History of Electric Vehicles" (available: May 2018).

[21] 2030.1.1-2015 - IEEE Standard Technical Specifications of a DC Quick Charger for Use with Electric Vehicles, February 2016, (available: July 2018).

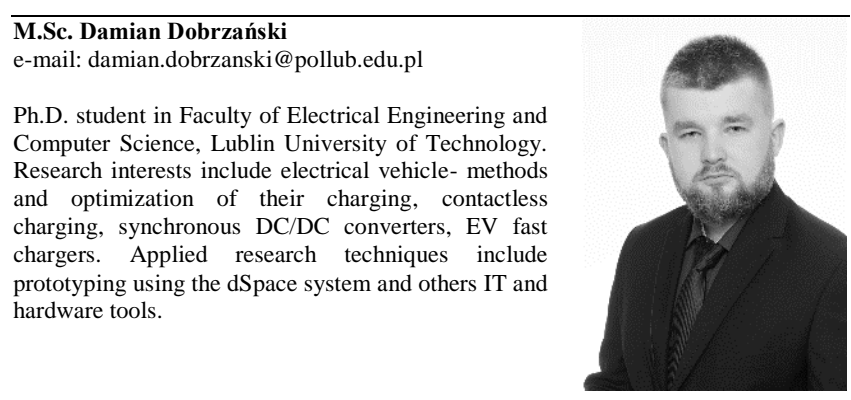

otrzymano/received: 4.08 .2018 przyjęto do druku/accepted: 15.09 .2018 